\title{
Linking spatial pattern of bottom fish assemblages with water masses in the North Sea
}

\section{SIEGFRIED EHRICH, ${ }^{1}$ VANESSA STELZENMÜLLER ${ }^{2, *}$ AND SARA ADLERSTEIN $^{3}$}

${ }^{1}$ Federal Research Institute for Rural Areas, Forestry and Fisheries; Institute of Sea Fisheries, Palmaille 9, D-22767

Hamburg, Germany

${ }^{2}$ CEFAS, Pakefield Road, Lowestoft NR33 OHT, UK

${ }^{3}$ School of Natural Resources and Environment, University of Michigan, 3010 Dana Building, Ann Arbor, MI 48109 1041, USA

\begin{abstract}
Understanding the links between large scale spatial structuring of fish assemblages and shaping factors is essential to develop comprehensive ecosystem-based fisheries management. In this study, we investigated spatial patterns of bottom fish assemblages in the North Sea in relation to prevailing water masses in the region. We based our analysis on catch data from the German Small-Scale Bottom Trawl Survey conducted between 1987 and 2005 and used both ordination techniques and Mantel tests. Spatial variability of bottom fish assemblages was larger than inter-annual variability. Five significantly different bottom fish assemblages were associated with the following prevailing hydrographical regimes: i) the English Channel, ii) Continental Coastal, iii) central North Sea, iv) northern North Sea, and v) northern Atlantic water masses. Associations were generated by gradients in relative proportions of abundant species such as grey gurnard (Eutrigla gurnardus), dab (Limanda limanda), whiting (Merlangius merlangus), haddock (Melanogrammus aeglefinus) and Norway pout (Trisopterus esmarki). Taking into account large scale spatial structuring of catch data Mantel tests confirmed significant correlation between the fish assemblages and hydrographical variables. In summary, our results strongly support the hypotheses that hydrographical features such as water masses, fronts, and residual currents could shape bottom
\end{abstract}

*Correspondence. e-mail: vanessa.stelzenmuller@cefas.co.uk Received 27 March 2008

Revised version accepted 2 November 2008 fish associations in the North Sea. Spatial demarcations of bottom fish assemblages indicated by this study can be used to support ecosystem-based fisheries management strategies.

Key words: bottom fish assemblages, hydrographical features, Mantel test, non-parametric MANOVA, North Sea, spatial community patterns, water masses

\section{INTRODUCTION}

Marine ecosystems are influenced by physical forces which cause structuring of biological communities. Significant relations have been found between single or combined environmental factors such as temperature and salinity with phytoplankton (Li et al., 1984), zooplankton (Roemmich and McGowan, 1995; Speckman et al., 2005), benthic communities (Bremner et al., 2006), fish larvae (Hsieh and Chiu, 2002), and fish (Anderson and Piatt, 1999). In particular, areas exposed to highly variable oceanographic conditions, such as coastal areas and adjacent shallow waters (Jaureguizar et al., 2006), and estuaries and bays (Jaureguizar et al., 2004; Speckman et al., 2005), are characterized by species associations adapted to environmental change. The linkage between environmental and oceanographic factors with fish assemblages is of particular interest in current fisheries research, as the understanding of spatio-temporal marine ecosystems dynamics is crucial for ecosystembased fisheries management and climate change impact assessments (Menge and Olson, 1990; Gaertner et al., 2005).

In the North Sea, studies have documented how oceanographic conditions influence fish community structures (Jennings et al., 2001; Southward et al., 2005). For example, for pelagic species such as Atlantic herring, studies revealed that North Sea currents and fronts act as barriers (Sinclair and Iles, 1985; Corten and Van der Kamp, 1992), and that densities of pelagic fish are high in areas located within current boundaries (see Maravelias et al., 2000). For bottom fish assemblages, habitat features such as depth, temperature, salinity, and sediment type are reported as boundaries (Daan et al., 1990; 
Greenstreet and Hall, 1996). For example, strong relations between the abundance of juvenile yellowtail flounder (Limanda ferruginea) and cold pool temperatures was demonstrated by Sullivan et al.(2005), showing the role of thermal habitats in fish population dynamics at early stages. On a local or regional spatial scale, numerous studies have investigated the association of bottom fish assemblages to environmental factors in the North Sea or enclosed seas (Daan et al., 1990; Greenstreet and Hall, 1996; Rogers and Millner, 1996; Ellis et al., 2000; Callaway et al., 2002). Independently from the area, studies have shown that the main driving forces forming communities structures are temperature and depth (Gomes and Headrich, 1992; Rogers and Millner, 1996; Ellis et al., 2000; Magnussen, 2002), or salinity and depth (Pierce and Mahmoudi, 2001). As yet, only a few studies have investigated the impact of oceanographic features on bottom fish assemblages over large spatial and temporal scales using surveys with standardized sampling designs (Gaertner et al., 2005). Thus, there is an urgent need to expand local and regional studies to larger scales (Mahon et al., 1998) to understand linkages of ecological pattern and structuring ecological processes (Gustafson, 1998).

In this study, we investigate linkages of spatial patterns in fish communities in the North Sea and prevailing hydrographical features. The North Sea is a heterogeneous body of water with large variations in depth, temperature, and salinity, and sub-regions have been defined based on hydrographical regimes (Dietrich, 1950; Laevastu, 1963; Lee, 1970, 1980; Otto et al., 1990). For this study we adopted the eight different water masses defined by Laevastu (1963). We used data from the German Small-Scale Bottom Trawl Survey (GSBTS), exceptional for its large temporal and spatial coverage and fine resolution. Since 1987 the GSBTS has sampled intensely areas located throughout the North Sea using a standardized sampling scheme (Ehrich et al., 2007). Areas sampled by GSBTS and used in this study were located in five of the eight different water masses proposed by Laevastu (1963). With the help of multivariate techniques this study aimed at identifying spatial patterns in fish assemblage structures, and to relate patterns to prevailing hydrographical features.

\section{MATERIALS AND METHODS}

The water masses of the North Sea

The North Sea is in connection with the North Atlantic in the north, with the Baltic Sea through
Skagerrak and Kattegat in the east and with the English Channel in the south. The strength of exchange depends on the currents mainly induced by strong winds from prevailing directions. During winter, water masses in the shallow southern areas as well as in the deeper northern North Sea are well mixed. In spring, the surface layer warms up and a thermocline develops northward from a transition line from northern Denmark to England (the Wash; nearly 50-m depth line), and separates the cold bottom water from the warm upper layer in the central and northern North Sea until autumn (Otto et al., 1990). The region with the greatest vertical contrast in temperature was found by Tomczak and Goedecke (1964) in the central North Sea and during summer, due to topography and circular currents, the coldest water at the bottom exists in the central North Sea, and temperatures increase towards the south as well as towards the north.

A division of the North Sea into sub-areas, e.g. by flushing times or the separation of North Sea water into different water masses, always have a somewhat arbitrary character (Otto et al., 1990). Hydrographical conditions such as run-off, are in permanent change and boundaries between the water masses are only based on mean conditions. Nevertheless, the definition and geographical identification of water masses done by Dietrich (1950) and Laevastu (1963) are useful, so that Lee (1980) defined a number of 'hydrographical regions' that more or less correspond with the areas occupied by these identified water masses, and more recent studies on water masses in the North Sea (Otto et al., 1990) are also based on these definitions.

For this study we used the chart of the distribution of water masses in the North Sea in summer given by Laevastu (1963), which differentiates eight water masses: North Atlantic Water, Channel Water, Skagerrak Water, Scottish Coastal Water, English Coastal Water, Continental Coastal Water, Northern North Sea Water and Central North Sea Water (Fig. 1). GSBTS sampling areas were located within the boundaries of five of these water masses.

Data for the study

We used data from the GSBTS database from surveys conducted annually between 1987 and 2005 from June to September, onboard the research vessels Walther Herwig, Walther Herwig III, SOLEA I and SOLEA II. Surveys were conducted in 12 sampling areas of $10 \times 10 \mathrm{~nm}$ ('boxes') located throughout the North Sea (Fig. 1). Fishing was performed with the Chalut à Grande Ouverture Verticale (GOV) on both Walther 


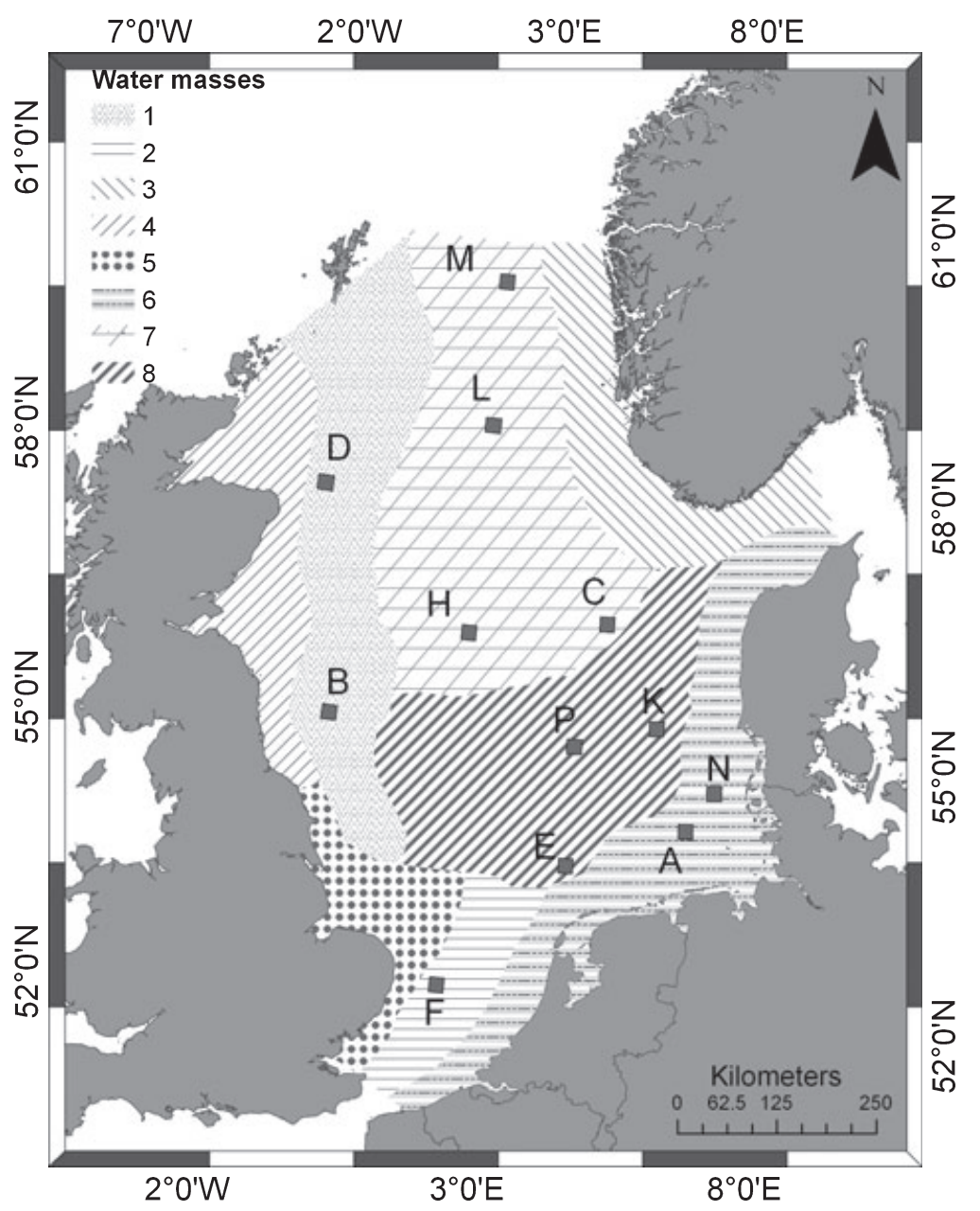

Figure 1. Location of sampling areas (boxes) for the study and North Sea distribution of water masses during summer after Laevastu (1963) 1 - North Atlantic Water, 2 - Channel Water, 3 - Skagerrak Water, 4 - Scottish Coastal Water, 5 - English Coastal Water, 6 - Continental Coastal Water, 7 - Northern North Sea Water, 8 Central North Sea Water.
Herwigs and with a cod trawl (CT) on both SOLEAs. The target trawling duration was $30 \mathrm{~min}$ at a speed of 4 knots for GOV and 3.5 knots for the CT gears. The location, as well as the trawl direction, within each GSBTS box was selected at random (Ehrich et al., 2007). Aboard, for each haul the entire catch was sorted according to species and enumerated; sub-samples were taken for abundant species. We used data from 2951 hauls, where the number of hauls sampled annually by box ranged from six to 39 (Table 1). Complementary to the biological programme, vertical profiles of temperature and salinity were obtained during most operations.

For the analysis of the fish assemblages we used numbers of fish by species caught by haul. Between 19 and 25 species (excluding eight pelagic species; see below) were recorded within a box and 81 species in all boxes during the study period. As we were investigating bottom fish assemblages and the gears were designed to sample demersal ground-fish, we excluded data from pelagic species such as herring (Clupea harengus), sprat (Sprattus sprattus), anchovy (Engraulis encrasicolus), pilchard (Sardina pilchardus), horse mackerel (Trachurus trachurus) and mackerel (Scomber scombrus). We also excluded species that were caught only once in a box, which resulted in a total number of 66 species considered for the subsequent analyses.

\section{Statistical analysis}

To investigate the linkage between spatial variability of fish assemblages and North Sea water masses we followed an explorative approach using ordination techniques and also Mantel tests (Legendre and Legendre, 1998).

We followed initially a bottom-up approach (see Eastwood et al., 2006) to analyse community associations from fish samples as we used non-metric multidimensional scaling (NMDS) (Faith et al., 1987; Clarke, 1993), which is a robust ordination technique. We calculated NMDS plots on the base of Bray-Curtis dissimilarity matrices (Bray and Curtis, 1957). We standardized fish numbers using a Wisconsin double 
Table 1. Number of hauls for which biological samples were taken, used in the study by sampling area (Box, in Fig. 1) and collected during summer (June-September) German Small-Scale Bottom Trawl Surveys.

\begin{tabular}{|c|c|c|c|c|c|c|c|c|c|c|c|c|}
\hline \multirow[b]{2}{*}{ Year } & \multicolumn{11}{|l|}{ Box } & \multirow[b]{2}{*}{ Total } \\
\hline & A & B & C & $\mathrm{D}$ & E & $\mathrm{H}$ & K & $\mathrm{L}$ & $\mathrm{M}$ & $\mathrm{N}$ & $\mathrm{P}$ & \\
\hline 1987 & 29 & 13 & 27 & 26 & & & & & & & & 95 \\
\hline 1988 & 26 & 17 & 25 & 25 & & & & & & & & 93 \\
\hline 1989 & 22 & 21 & 25 & 24 & 25 & & & & & & & 117 \\
\hline 1990 & 23 & 23 & 25 & 34 & 8 & & & & & & & 113 \\
\hline 1991 & 27 & 24 & 27 & 26 & 28 & 27 & 24 & & & & & 183 \\
\hline 1992 & 27 & 23 & 23 & 19 & 28 & 23 & 19 & & & & & 162 \\
\hline 1993 & 6 & 15 & 11 & 20 & 27 & 25 & 27 & & & & & 131 \\
\hline 1994 & 21 & 19 & 21 & 39 & 19 & 27 & 26 & & & & & 172 \\
\hline 1995 & 22 & 19 & 21 & 24 & 21 & 26 & 24 & & & & & 157 \\
\hline 1996 & 23 & 18 & 23 & 18 & 27 & 17 & 28 & & & & & 154 \\
\hline 1997 & 21 & 22 & 15 & 15 & 6 & 25 & 26 & & & & & 130 \\
\hline 1998 & 24 & 19 & 20 & 19 & 17 & 50 & 23 & & & & & 172 \\
\hline 1999 & 24 & 24 & 23 & 28 & 10 & 17 & 30 & 20 & 23 & & & 199 \\
\hline 2000 & 21 & 16 & 15 & - & - & - & - & - & - & 8 & & 60 \\
\hline 2001 & 18 & 21 & 23 & 22 & 18 & 27 & 22 & 24 & 24 & 16 & & 215 \\
\hline 2002 & 19 & 21 & 22 & 21 & 15 & 17 & 9 & 20 & 21 & & & 165 \\
\hline 2003 & 20 & 21 & 14 & 21 & 15 & 23 & 24 & 21 & 21 & & 24 & 204 \\
\hline 2004 & 27 & 21 & 21 & 21 & 19 & 23 & 17 & 19 & 21 & 15 & 16 & 220 \\
\hline 2005 & 26 & 21 & 16 & 21 & 14 & 20 & 14 & 21 & 21 & 20 & 15 & 209 \\
\hline Total & 426 & 378 & 397 & 463 & 297 & 347 & 313 & 125 & 131 & 59 & 55 & 2951 \\
\hline
\end{tabular}

standardization, where species are first standardized by their maxima and then by site totals (Oksanen, 1983; Legendre and Gallagher, 2001). With the help of NMDS plots we explored spatial variability of fish communities among boxes and classified them into clusters. We also produced NMDS plots with site scores labelled according to the boxes (Table 2), the location within water masses, and the species in the

Table 2. Location of sampling areas (Box, in Fig. 1) within water masses proposed by Laevastu (1963) and according to prevailing hydrographical conditions during the study (1987-2005).

\begin{tabular}{lll}
\hline Box & North Sea water masses & Code \\
\hline A & Continental Coastal & CC \\
N & Continental Coastal & CC \\
B & Northern Atlantic & NA \\
D & Northern Atlantic & NA \\
H & Northern North Sea & NNS \\
C & Northern North Sea & NNS \\
E & Central North Sea & CNS \\
K & Central North Sea & CNS \\
P & Central North Sea & CNS \\
F & Channel & C \\
L & Northern North Sea & NNS \\
M & Northern North Sea & NNS \\
\hline
\end{tabular}

(C) 2009 The Authors, Fish. Oceanogr., 18:1, 36-50. assemblages. Hence, we superimposed a classification scheme based on both the hydrographical conditions and the degree of overlap of the site scores.

Subsequently, we explored the variability of the fish composition among associated clusters, boxes and/or sampling years by conducting a permutational multivariate analysis of variance using distance matrices, which allows for a direct additive partitioning of the variation (Anderson, 2001). This method is also referred to as nonparametric MANOVA. Significance tests are based on F-tests using sequential sums of squares from permutation of the raw data.

We then calculated similarity percentages (SIMPER; Clarke, 1993) to identify which species contributed most to the similarity within clusters (typifying species) and dissimilarity (discriminating species) between clusters. The method is based on the analysis of Bray-Curtis similarity matrices derived from cluster-species compositions within and between the categorized assemblages. We used square roottransformed mean abundances for the SIMPER analysis. We considered species within each assemblage as typifying species if they contributed to the top $90 \%$ of average similarity within the assemblage, and as discriminating species if they contributed to the top $90 \%$ of dissimilarity between assemblages. 
To further test the link between fish assemblages and the distinct water masses we computed Mantel tests and partial Mantel tests for correlation between distance (dissimilarity) matrices (Legendre and Legendre, 1998). We used only box-year combinations where average data on both abundance and hydrographical measurements were available (98 boxyear combinations; 892 hauls with hydrographical measurements). We further used Wisconsin standardized species abundances to compute a Bray-Curtis dissimilarity matrix (referred to as bio). The second dissimilarity matrix (referred to as hydro) was based on the hydrographical variables bottom temperature, bottom salinity, surface temperature and surface salinity using Euclidean distances. The third matrix (referred to as space) was the relative geographical distance between boxes. With this analysis we tested whether samples that were hydrographically similar were also similar in fish composition, whether samples that were close together were also compositionally similar, and whether samples that were close together were also hydrographically similar. Then, we computed partial Mantel tests (Mantel, 1967; Smouse et al.,1986) taking into account the relative geographical distances between sample locations (Legendre et al., 2005). These provide information on the spatial relationships between fish assemblages and hydrographical variables while accounting for spatial structure within the data by testing whether samples that are hydrographically similar are also similar in fish composition, controlling for the space effect. We calculated all tests with 1000 permutations based on the Pearson correlation.

We computed NMDS plots, nonparametric MANOVA and Mantel tests using the package 'vegan'
(Oksanen et al., 2007) available within the statistical programming environment $\mathrm{R}$ ( $\mathrm{R}$ Development Team, 2007), and we conducted SIMPER analyses with PRIMER v5 (Plymouth Marine Laboratory, Plymouth, UK).

\section{RESULTS}

Hydrographical conditions in the study areas

Hydrographical information obtained during GSBTS allowed confirmation of the origin of the water masses dominating the sampling areas. Bottom water temperatures and salinities among boxes ranged respectively from about 4 to $20^{\circ} \mathrm{C}$ and $31.7-35.4$, surface water temperatures and salinities from 8.5 to $20.2^{\circ} \mathrm{C}$ and 29.9-35.4, and water depth from 17 to $119 \mathrm{~m}$ (Table 3). Boxes $\mathrm{A}$ and $\mathrm{N}$ were dominated by Continental Water masses, generally well mixed, except when wind and weather introduced a low salinity surface layer caused by river runoff. Stratification developed by heating of the surface during calm high pressure weather. In Box $\mathrm{N}$, the oxygen content of the bottom layer was reduced to critical values when undisturbed for some weeks. Boxes B and D were dominated by relatively stable North Atlantic Water masses characterized by a thermocline and occasionally a second near surface temperature stratification developed when Scottish Coastal Water was driven by stable westerly winds. Boxes $\mathrm{C}, \mathrm{H}, \mathrm{L}$ and $\mathrm{M}$ were dominated by vertically homohaline Northern North Sea Water masses, with a persistent thermocline. In Box C, Norwegian Deep Water moved temporarily in the near bottom layer, with temperatures and salinities originating from the Atlantic Inflow. Long-lasting winds of northeast direction caused Baltic Outflow Water to generate a thin near-surface halocline plus

Table 3. Depth, bottom water temperature and salinity, and surface temperature and salinity measured within sampling areas (Box, in Fig. 1) during summer (1987-2005).

\begin{tabular}{lccccc}
\hline Box & $\begin{array}{l}\text { Depth } \\
\text { range }(\mathrm{m})\end{array}$ & $\begin{array}{l}\text { Bottom temperature } \\
\text { range }\end{array}$ & $\begin{array}{l}\text { Surface temperature } \\
\text { range }\end{array}$ & $\begin{array}{l}\text { Bottom salinity } \\
\text { range }\end{array}$ & $\begin{array}{l}\text { Surface salinity } \\
\text { range }\end{array}$ \\
\hline A & $36-45$ & $8.23-18.57$ & $9.87-20.19$ & $32.00-34.30$ & $29.87-34.09$ \\
B & $68-81$ & $5.97-8.72$ & $11.60-19.20$ & $34.64-35.04$ & $32.67-34.97$ \\
C & $55-65$ & $4.08-9.70$ & $12.71-18.57$ & $34.26-35.12$ & $33.40-35.06$ \\
D & $90-115$ & $6.47-10.35$ & $8.53-17.08$ & $34.66-35.32$ & $34.03-35.31$ \\
E & $36-44$ & $14.86-16.52$ & $15.81-19.44$ & $33.93-34.95$ & $33.78-34.83$ \\
F & $42-53$ & $15.76-17.20$ & $15.92-17.80$ & $34.05-34.96$ & $33.70-34.75$ \\
H & $69-78$ & $6.20-7.79$ & $13.93-18.49$ & $34.90-35.95$ & $33.89-35.43$ \\
K & $37-44$ & $11.01-14.36$ & $15.21-18.64$ & $34.11-34.62$ & $33.82-34.59$ \\
L & $105-119$ & $6.58-7.73$ & $13.34-17.01$ & $35.03-35.34$ & $33.50-35.26$ \\
M & $83-112$ & $7.02-8.94$ & $8.61-18.49$ & $35.18-35.97$ & $32.35-35.43$ \\
N & $17-26$ & $15.38-20.08$ & $15.61-20.17$ & $31.33-32.29$ & $31.33-32.28$ \\
P & $43-50$ & $8.42-10.96$ & $15.43-18.70$ & $34.26-34.93$ & $34.54-34.98$ \\
\hline
\end{tabular}


thermocline. In Box $\mathrm{H}$, short-term variability was the weakest among all boxes due to similarity of surrounding water masses and minimum advective transport. Depending on winds and heating phases, seasonal temperature stratification showed a staircaselike vertical temperature profile. Bottom water mass conserved the lowest North Sea temperatures. In Boxes $\mathrm{L}$ and $\mathrm{M}$, seasonal changes in salinity and thermal stratification occurred. Salinity stratification, slightly higher in Box M, depended on the amount of intermediate water from the Norwegian Trench crossing towards the central North Sea. Boxes E, K and $\mathrm{P}$ were dominated by Central North Sea Water masses. Box E was vertically homogeneous and occasionally English Channel Water or even Continental Coastal Water moved into the area. Depending on meteorological conditions, water mass of only one origin or a mix of up to all three waters was found. In Box K and P thermal stratification developed (stronger in Box P) but no salinity differences. Box $F$ was dominated by Channel Water masses, generally well mixed. Salinity and temperature stratifications developed when wind fields induced overlay of Coastal Water with varying parts of Thames Water or Wash Bay Water. A more detailed description on the hydrographical conditions within boxes during summer and other times of the year can be found in Ehrich et al. (2007).

\section{Linking bottom fish assemblages to water masses}

The most abundant demersal species in the catch (Table 4), which contributed to about $95 \%$ of the total were: whiting (Merlangius merlangus; 28.2\%), Norway pout (Trisopterus esmarki; 26.2\%), haddock (Melanogrammus aeglefinus; 21.5\%), dab (Limanda limanda; 14.6\%), long rough dab (Hippoglossoides platessoides; $2.9 \%$ ) and grey gurnard (Eutrigla gurnardus; $1.7 \%$ ).

The NMDS plot with site scores labelled according to boxes (Fig. 2a) allows three major clusters to be distinguished: one corresponds to box F separated without overlap from other boxes; a second consists of Boxes A, N, E, K and P (all situated in the southern part of the North Sea with depths shallower than $50 \mathrm{~m}$ ); and a third contains Boxes C, H, L, M, B and D (situated in areas deeper than $50 \mathrm{~m}$ with thermally stratified water masses in summer). More details became apparent within the latter two clusters when additional analyses were performed. The NMDS plot with site scores labelled according to water masses (Fig. 2b) shows a clear separation of ground-fish species assemblages according to the five water masses within which they were located. A first cluster contains Box F and corresponds to the Channel (CC)
Water; a second contains Boxes $\mathrm{A}$ and $\mathrm{N}$ and corresponds to the Continental Coastal (CCC) Water; a third contains Boxes $\mathrm{E}, \mathrm{K}$, and $\mathrm{P}$ and corresponds to the Central North Sea (CNSC) Water; a fourth contains Boxes $\mathrm{H}, \mathrm{C}, \mathrm{L}$, and $\mathrm{M}$ and corresponds to the Northern North Sea (NNSC) Water, and the fifth contains boxes B and D and corresponds to the North Atlantic (NAC) Water (Table 2, Fig. 1). Clearly, clusters CCC, CNCS, NAC, and NNSC were disconnected from cluster CC. A second gradient separated northern clusters (NAC and NNSC) from southern clusters (CCC and CNSC). The NMDS plots with sites scores labelled according to species (Fig. 2c) allowed the characterization of their importance in the respective assemblages. Widespread and highly abundant species such as whiting, grey gurnard or dab appear closer to the centre of the NMDS plot. Species rather associated to the northern clusters (NNS and NA) were for example saithe (Pollachius virens), blue whiting (Microstomus poutassou), and starry smooth-hound (Mustelus asterias), whereas lesser weever (Echiichthys vipera), and pouting (Trisopterus luscus) are plotted relative close to the Channel cluster. In contrast, flatfish species such as flounder (Platichthys flesus) and solenette (Buglossidium luteum) characterized the Continental Coastal Cluster.

The results of the nonparametric MANOVA revealed significant variation of fish assemblages among boxes $[F(11,143)=11.04, P<0.001$, partial $\left.r^{2}=0.459\right]$, and significant variation among clusters $\left[F(4,150)=16.38, P<0.001\right.$, partial $\left.r^{2}=0.304\right]$. In contrast, results did not show significant variation of fish assemblages among years $[F(19,135)=0.93$, $P=0.703$, partial $\left.r^{2}=0.116\right]$. The interaction between the factors cluster and sampling year was significant $[F(89,65)=1.64, \quad P<0.001, \quad$ partial $\left.r^{2}=0.692\right]$. Thus, the results of both the NMDS plots and MANOVA indicate that spatial variability dominated over temporal variability.

Species abundances and relative importance of the 66 species selected varied among the five assemblages identified (Table 4; Fig. 3). Species with highest abundances (rank 1-3) in more than one cluster were dab (three clusters), haddock (two clusters), whiting (four clusters), and Norway pout (two clusters) (Table 4; Fig. 3).

The Continental Coastal (CC) assemblage was characterized by high abundances of dab, whiting and greater sandeel (Hyperoplus lanceolatus) and contributions of anadromous species such as European river lamprey (Lampetra fluviatilis), sea lamprey (Petromyzon marinus), sea trout (Salmo trutta), flatfishes such as flounder and solenette, and species tolerant of brackish 
Table 4. Mean catch rates (numbers in 30-min tows) by species retained for the analysis and sampled in 1987-2005 in GSBTS boxes within the five hydrographical areas in Fig. 1. Codes are as in Table 1. Ranks 1-3 per cluster are in bold.

\begin{tabular}{|c|c|c|c|c|c|c|}
\hline \multirow[b]{2}{*}{ Species } & \multirow[b]{2}{*}{ Sp. code } & \multicolumn{5}{|l|}{ Cluster } \\
\hline & & NNSC & NAC & $\mathrm{CCC}$ & CNSC & $\mathrm{CC}$ \\
\hline Agonus cataphractus & Ago.cata & 0.04 & 0.06 & 0.56 & 0.02 & \\
\hline Ammodytes marinus & Amm.mari & 8.85 & 78.23 & 23.20 & 0.01 & 0.01 \\
\hline Anarhichas lupus & Ana.lupu & 0.18 & 0.29 & & & \\
\hline Argentina silus & Arg.silu & 0.05 & & & & \\
\hline Argentina sphyraena & Arg.sphy & 4.69 & 2.98 & & & \\
\hline Arnoglossus laterna & Arn.late & & & 2.27 & 0.38 & \\
\hline Aspitrigla cuculus & Asp.cucu & 0.01 & 0.03 & & & 0.95 \\
\hline Buglossidium luteum & Bug.lute & & & 21.62 & 0.55 & \\
\hline Callionymus lyra & Cal.lyra & 0.61 & 1.02 & 8.42 & 15.90 & 0.01 \\
\hline Callionymus maculatus & Cal.macu & 0.19 & 0.11 & 0.04 & 0.07 & \\
\hline Callionymus reticulatus & Cal.retic & 0.01 & & & & \\
\hline Cyclopterus lumpus & Cyc.lump & 0.03 & 0.01 & & 0.01 & \\
\hline Echiichthys vipera & Ech.vipe & & & 0.16 & 0.26 & 11.73 \\
\hline Entelurus aequoreus & Ent.aequ & 0.21 & 0.03 & 0.02 & & \\
\hline Eutrigla gurnardus & Eut.gurn & 54.74 & 91.91 & 69.20 & 40.69 & 6.61 \\
\hline Gadiculus argenteus & Gad.arge & & 0.01 & & & \\
\hline Gadus morhua & Gad.morh & 59.64 & 10.73 & 53.83 & 29.44 & 10.35 \\
\hline Galeorhinus galeus & Gal.gale & & & & 0.02 & 0.02 \\
\hline Glyptocephalus cynoglossus & Gly.cyno & 0.24 & 0.27 & & & \\
\hline Helicolenus dactylopterus & Hel.dact & & 0.02 & 0.01 & & \\
\hline Hippoglossoides platessoides & Hip.plat & 247.62 & 102.61 & 0.13 & 8.61 & 0.01 \\
\hline Hippoglossus hippoglossus & Hip.hipp & 0.06 & 0.02 & & & \\
\hline Hyperoplus lanceolatus & Hyp.lanc & 2.30 & 0.01 & 129.71 & 0.54 & 1.89 \\
\hline Lampetra fluviatilis & Lam.fluv & & & 0.09 & & \\
\hline Lepidorhombus whiffiagonis & Lep.whif & 0.03 & 0.02 & & & \\
\hline Limanda limanda & Lim.lima & 597.56 & 200.45 & 1403.94 & 278.59 & 3.87 \\
\hline Lophius piscatorius & Lop.pisc & 0.50 & 0.21 & & & \\
\hline Lumpenus lampretaeformis & Lum.lampr & 0.03 & & & & \\
\hline Melanogrammus aeglefinus & Mel.agle & 924.32 & 1844.87 & 0.56 & 0.72 & 0.08 \\
\hline Merlangius merlangus & Mer.merla & 505.70 & 1829.99 & 799.90 & 787.80 & 598.42 \\
\hline Merluccius merluccius & Mer.merlu & 0.48 & 0.08 & 0.35 & 0.41 & \\
\hline Micromesistius poutassou & Mic.pout & & 0.01 & & & 0.01 \\
\hline Microstomus kitt & Mic.kitt & 10.34 & 38.11 & 3.93 & 1.49 & 0.29 \\
\hline Molva molva & Mol.molv & 0.05 & 0.13 & & 0.01 & 0.01 \\
\hline Mullus surmuletus & Mul.surm & 0.01 & 0.01 & 3.36 & 0.69 & 0.16 \\
\hline Mustelus asterias & Mus.aste & & 0.03 & & & \\
\hline Mustelus mustelus & Mus.must & & & & & 0.01 \\
\hline Myoxocephalus scorpius & Myo.scor & & & 0.32 & 0.01 & \\
\hline Myxine glutinosa & Myx.glut & 0.04 & 0.22 & & & \\
\hline Nerophis ophidion & Ner.oph & 0.01 & & & & \\
\hline Petromyzon marinus & Pet.mari & & & 0.01 & & \\
\hline Platichthys flesus & Pla.fles & & & 0.26 & 0.01 & \\
\hline Pleuronectes platessa & Ple.plat & 4.26 & 17.71 & 23.79 & 34.95 & 0.39 \\
\hline Pollachius pollachius & Pol.poll & 0.01 & & & & \\
\hline Pollachius virens & Pol.vire & 40.09 & 0.73 & & 0.01 & 0.01 \\
\hline Pomatoschistus minutus & Pom.minu & 0.03 & 0.01 & 1.26 & 0.02 & \\
\hline Psetta maxima & Pse.maxi & 0.05 & 0.06 & 0.39 & 0.20 & \\
\hline Raja clavata & Raj.clava & 0.02 & 0.02 & & & 0.02 \\
\hline Raja montagui & Raj.mont & & & & & 0.02 \\
\hline Raja naevus & Raj.naev & & 0.76 & & & \\
\hline
\end{tabular}


Table 4. Continued.

\begin{tabular}{|c|c|c|c|c|c|c|}
\hline \multirow[b]{2}{*}{ Species } & \multirow[b]{2}{*}{ Sp. code } & \multicolumn{5}{|l|}{ Cluster } \\
\hline & & NNSC & NAC & $\mathrm{CCC}$ & CNSC & $\mathrm{CC}$ \\
\hline Raja radiata & Raj.radi & 4.57 & 1.73 & & & \\
\hline Rhinonemus cimbrius & Rhi.cimb & & & 0.44 & 3.37 & \\
\hline Salmo trutta & Sal.trut & & & 0.01 & & \\
\hline Scophthalmus rhombus & Sco.rhom & & & 0.15 & 0.07 & \\
\hline Scyliorhinus canicula & Scy.cani & 0.01 & 0.36 & 0.01 & 0.01 & 0.09 \\
\hline Sebastes viviparus & Seb.vivi & 0.01 & 0.02 & & & \\
\hline Solea vulgaris & Sol.vulg & & & 0.22 & 0.03 & \\
\hline Spondyliosoma cantharus & Spo.cant & & & & & 0.01 \\
\hline Squalus acanthias & Squ.acan & 0.06 & 0.31 & & 0.01 & 0.01 \\
\hline Syngnathus rostellatus & Syn.rost & & & 0.03 & & \\
\hline Trachinus draco & Tra.drac & & & & & 0.20 \\
\hline Trigla lucerna & Tri.luce & & 0.01 & 3.04 & 0.11 & \\
\hline Trisopterus esmarki & Tri.esma & 1032.80 & 2357.31 & 0.01 & 0.03 & 0.01 \\
\hline Trisopterus luscus & Tri.lusc & & 0.02 & 0.63 & 0.58 & 11.93 \\
\hline Trisopterus minutus & Tri.minu & 0.88 & 12.98 & 4.83 & 14.27 & 74.21 \\
\hline Zeus faber & Zeu.fabe & & 0.06 & & 0.01 & \\
\hline
\end{tabular}

environment such as sand goby (Pomatoschistus minutus) and short-horn sculpin (Myoxocephalus scorpius). Both lamprey species and sea trout and Nilsson's pipefish (Syngnathus rostellatus) were exclusively caught within the CC assemblage. The Central North Sea (CNS) fish assemblage was dominated by whiting, dab and grey gurnard, and also characterized by the relatively high occurrence of fourbeard rockling (Rhinonemus cimbrius). In the Channel (C) assemblage the most abundant species were whiting, poor cod (Trisopterus minutus), and bib (Trisopterus luscus). Species well represented only in the $\mathrm{C}$ assemblage were sharks and rays such as smooth-hound (Mustelus mustelus) and spotted ray (Raja montagui), black seabream (Spondyliosoma cantharus), and greater weever (Trachinus draco). The Northern North Sea (NNS) assemblage was dominated by Norway pout, haddock, and dab and characterized by high representations of greater argentine (Argentina silus), snakeblenny (Lumpenus lampretaeformis), straightnose pipefish, pollack (Pollachius pollachius), and saithe, which were nearly absent in the Channel and more southern clusters. The three most abundant species in the North Atlantic assemblage (NA) were Norway pout, haddock, and whiting. The less abundant silvery cod (Gadiculus argenteus), starry smooth-hound (Mustelus asterias), and cuckoo ray (Raja naevus) characterized this assemblage as they were absent in all others.

The highest average similarity within clusters $(65.73 \%)$ was obtained for the NAC cluster and the lowest similarity $(54.69 \%)$ for the CCC cluster.
Between six and seven typifying species were identified for each cluster, whereas grey gurnard, dab and whiting were among the typifying species in all clusters (Table 5). The typifying species of the southern clusters CCC and CNSC were similar except for solenette, which was a typifying species only of cluster CCC. Typifying species of the northern clusters NAC and NNSC were more variable.

High dissimilarities were found between northern and southern clusters, whereas lower dissimilarities were found among northern clusters and southern clusters (Table 6). Lesser weever, pouting, and poor cod contributed greatly to the discrimination of the CC cluster, as these species were defined as typifying species only in that cluster. In general, E. gurnardus, L. limanda and M. merlangus contributed to the discrimination of each cluster combination. The separation of the southern clusters was mainly due to $L$. limanda and M. merlangus, whereas the distinction of the northern clusters was mainly caused by M. aeglefinus, M. merlangus and T. esmarki.

Mantel tests revealed that samples similar in species composition came from areas with similar hydrographical characteristics (bio versus hydro, Mantel statistic: $0.4205, P<0.001$ ), samples similar in species composition were also closer together (bio versus space, Mantel statistic: $0.7013, P<0.001)$ and samples that were closer together came from areas hydrographically similar (hydro versus space, Mantel statistic: 0.2962, $P<0.001$ ). Further, the result of the partial Mantel test, which considered the relative geographical 

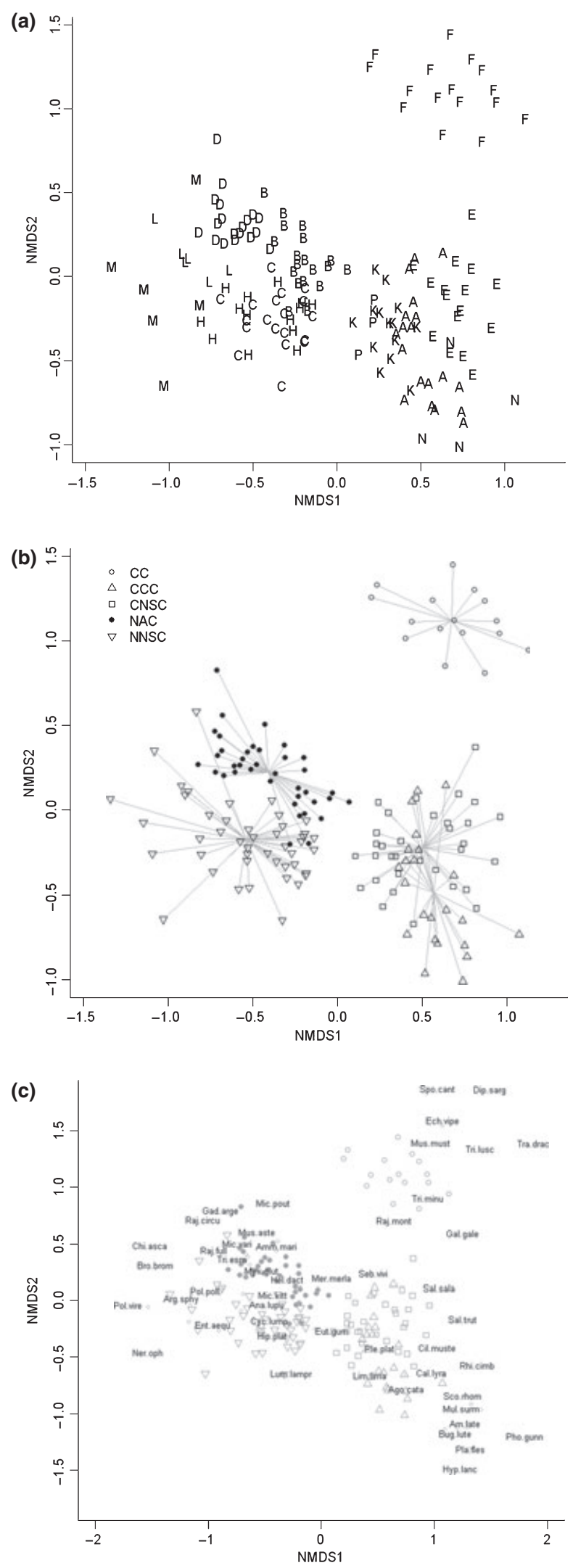

Figure 2. NMDS plot based on annual means of species composition of catches in sampling areas (boxes) A-P in Fig. 1 from samples collected from 1987 to 2005 based on: a) boxes, b) water masses $(\bigcirc)$, Continental Costal $(\triangle)$, Central North Sea $(\square)$, Northern Atlantic $(\mathbf{O})$ and Northern North Sea $(\nabla)$ Waters, and c) most abundant species (Table 4).

distance between boxes, showed a clear correlation between species composition and hydrographical conditions (Mantel statistic: 0.3124, $P<0.001$ ).

\section{DISCUSSION}

In this study, we linked large scale spatial variability of fish assemblages in the North Sea and water masses, based on data from a long-term monitoring effort, the GSBTS. Our findings showed on a large spatial scale five significantly distinct clusters of bottom fish associations. Assemblages are species that tend to co-occur because they have similar habitat preferences (Mahon et al., 1998). Associations showed a strong degree of persistence, as the assemblages were distinguishable throughout the study period. Although interannual stability of fish assemblages was shown by the dominance of spatial variability over temporal variability by the nonparametric MANOVA, sampling effort across the boxes varied among years (Table 1), which could have affected the analysis.

We used ordination techniques to explore fish assemblage associations and to define clusters of GSBTS sampling areas (boxes) based on species composition and location within North Sea water masses following a combined bottom-up and top-down approach (see Eastwood et al., 2006). Eastwood et al. (2006) showed that the use of the top-down approaches by superimposing a physical classification scheme could lead to imprecise biological assemblage maps. Other approaches to identify fish assemblages use combinations of cluster analysis with Bayesian multinomial logit models to calculate the likelihood of samples to belong to clusters (see Jørgensen et al., 2005). Our approach to define clusters of GSBTS boxes was a combination of both approaches, bottomup and top-down, which is based on similar associations and the location of boxes within water masses. Ultimately, this allowed us to test the hypotheses that large scale spatial variation of fish assemblages was linked to the hydrographical conditions.

Species most influential in defining the fish assemblages were common species such as grey gurnard, dab, whiting, and haddock, which is in 
agreement with results in the north-western North Sea showing that differences in assemblages among three regions over a century of intensive fishing could be explained by changes in abundance of common species such as Norway pout and whiting (Greenstreet and Hall, 1996). Previous studies within GSBTS sampling areas showed that the link between fish assemblages and water masses during summer is underpinned by the proportion of species of southern origin (Lusitanian fauna) in the catch, with a highly significant positive correlation with bottom temperature (Ehrich and Stransky, 2001). In our study, proportions of southern origin were also by far the lowest (13-19\%) where water was coldest (Boxes $\mathrm{H}$ and $\mathrm{C}$ ) and increased to the south (47-48\%) and to the north (22-33\%) where temperatures were highest (Boxes $\mathrm{A}, \mathrm{E}$ and $\mathrm{F}$ and Boxes $\mathrm{B}, \mathrm{D}, \mathrm{L}$ and $\mathrm{M}$, respectively).

The separation between southern and northern clusters is consistent with the position of the most important boundary in the North Sea, which represents the lower boundary line between stratified and mixed water masses (at 40-50 m depth), and is in line with studies of the North Sea bottom fish fauna by Daan et al. (1990) and Callaway et al. (2002). The first study, based on cluster analysis and mean catches of the 50 most abundant species in the English groundfish surveys from 1982 to 1986, defined three zoogeographical units, the shelf edge, central and northern, and southern regions, with the divisions between southern and northern regions along the 40-m depth contour. The most abundant species in the southern region were dab, whiting, grey gurnard and plaice (Pleuronectes platessa), the same species that in our study were dominant within southern clusters (CCC and CNSC). The central and northern region in Daan et al. (1990) was dominated by haddock, whiting, cod, and Norway pout. The region corresponds to the Central North Sea and the North Atlantic regions in our study, and although we found that haddock and whiting dominated the catch in both regions, we also found dab and long rough dab to be also important in the Central North Sea, and dab and Norway pout to be important in the North Atlantic region. The absence of cod as dominant species in our study reflects the decreasing trend in the cod stock during the last decades (Holmes et al., 2008; Gray et al., in press). The second study by Callaway et al. (2002) classified the North Sea fish fauna into five sub-communities, three in the southern, one in the central, and one in the northern North Sea. Sub-communities were divided along the 50-, 100- and 200-m depth contours and near the entrance of the English Channel. The analysis in the study included pelagic species and was based on data from only one summer, collected during the 2000 International Bottom Trawl Survey, and results were not comparable with ours using meso-scaled sampling areas and those from Daan et al. (1990).

The North Sea fish assemblages identified in our study may not be fully representative for bottom fish communities in the surveyed areas as catch was influenced by selectivity of the trawl gear. The bottom trawl gear catches a variety of species ranging from those buried in the sediment such as flatfishes, to those found in the upper layer of the water column such as mackerel and scad. Further, during fishing operations, the contact of the rubber disk ground ropes to the bottom was weak, and species living very close to the bottom like solenette, scaldfish (Arnoglossus laterna) and hooknose (Agonus cataphractus) can be underrepresented in the catch. These species constituted $<5 \%$ of catch, much less than the catch of a beamtrawl (S. Ehrich, unpublished data). Nevertheless, we do not expect our findings of spatial patterns of fish communities and linkages with water masses to be affected by gear selectivity, as highly standardized methods were followed during GSBTS.

A general factor that can affect spatial analysis of fish assemblages is autocorrelation resulting from spatial structure in catch data (Petitgas, 2001). Recent studies using GSBTS data showed spatial autocorrelation at the scale of the boxes and the impact of water depth and survey scale on the spatial structuring of catch data (Stelzenmüller et al., 2004, 2005). The spatial scale of the box seemed to be the threshold at which spatial autocorrelation can hamper estimations of mean catches and associated variances, and habitat association was more pronounced with increasing spatial scale for species such as haddock and whiting (Stelzenmüller et al., 2005). Here, we controlled the effect of spatial distance between boxes when we assessed the link between fish associations and the hydrographical environment by computing partial Mantel tests. Our results further showed significant linkage between bottom fish assemblages and hydrographical environment.

The structure of fish assemblages in the North Sea is strongly influenced by ontogenetic, spawning and feeding migrations of several fish species (Daan et al., 1990). Analysis of bottom fish assemblages in this study are based on summer distribution and the degree of seasonal variation cannot be estimated due to lack of data. Nevertheless, we do not expect significant seasonal changes as movements of demersal fish are rather local compared with seasonal North Sea-wide migrations described for pelagic species such as herring, mackerel and scad (Knijn et al., 1993). 

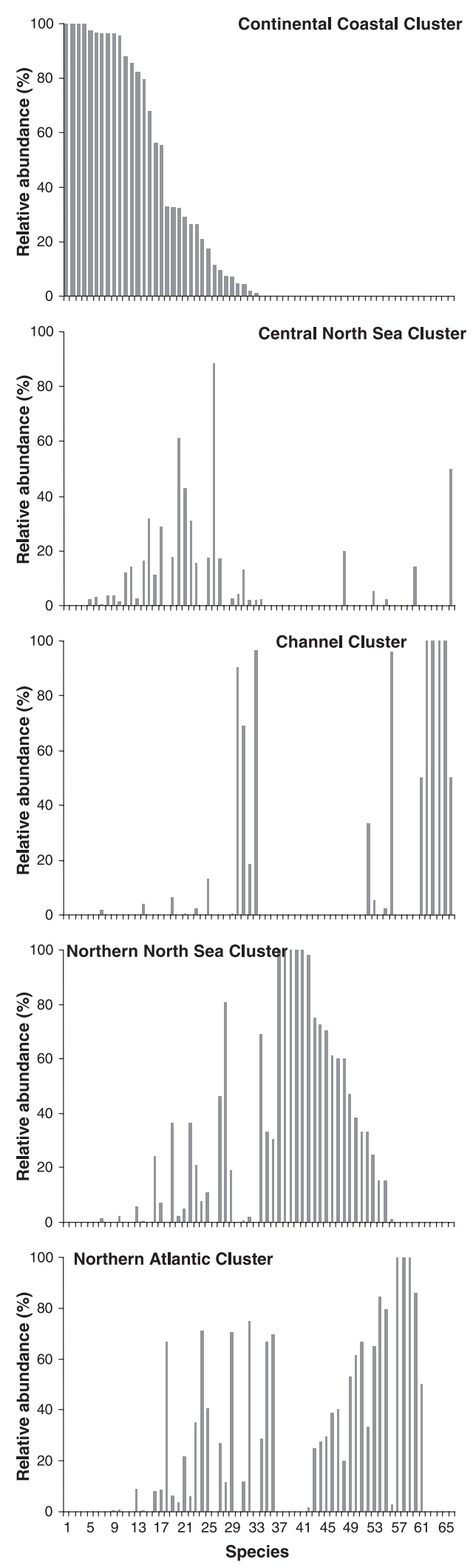

Species CCC CNSC CC NNSC NAC

\begin{tabular}{|c|c|c|c|c|c|c|}
\hline 1 & Lam.fluv & 100 & 0 & 0 & 0 & 0 \\
\hline 2 & Pet.mari & 100 & 0 & 0 & 0 & 0 \\
\hline 3 & Sal.trut & 100 & 0 & 0 & 0 & 0 \\
\hline 4 & Syn.rost & 100 & 0 & 0 & 0 & 0 \\
\hline 5 & Bug.lute & 98 & 2 & 0 & 0 & 0 \\
\hline 6 & Myo.scor & 97 & 3 & 0 & 0 & 0 \\
\hline 7 & Hyp.lanc & 96 & 0 & 1 & 2 & 0 \\
\hline 8 & Pla.fles & 96 & 4 & 0 & 0 & 0 \\
\hline 9 & Tri.luce & 96 & 3 & 0 & 0 & 0 \\
\hline 10 & Pom.minu & 95 & 2 & 0 & 2 & 1 \\
\hline 11 & Sol.vulg & 88 & 12 & 0 & 0 & 0 \\
\hline 12 & Arn.late & 86 & 14 & 0 & 0 & 0 \\
\hline 13 & Ago.cata & 82 & 3 & 0 & 6 & 9 \\
\hline 14 & Mul.surm & 79 & 16 & 4 & 0 & 0 \\
\hline 15 & Sco.rhom & 68 & 32 & 0 & 0 & 0 \\
\hline 16 & Lim.lima & 57 & 11 & 0 & 24 & 8 \\
\hline 17 & Pse.maxi & 56 & 29 & 0 & 7 & 9 \\
\hline 18 & Hel.dact & 33 & 0 & 0 & 0 & 67 \\
\hline 19 & Gad.morh & 33 & 18 & 6 & 36 & 7 \\
\hline 20 & Cal.lyra & 32 & 61 & 0 & 2 & 4 \\
\hline 21 & Ple.plat & 29 & 43 & 0 & 5 & 22 \\
\hline 22 & Mer.merlu & 27 & 31 & 0 & 36 & 6 \\
\hline 23 & Eut.gurn & 26 & 15 & 3 & 21 & 35 \\
\hline 24 & Amm.mari & 21 & 0 & 0 & 8 & 71 \\
\hline 25 & Mer.merla & 18 & 17 & 13 & 11 & 40 \\
\hline 26 & Rhi.cimb & 12 & 88 & 0 & 0 & 0 \\
\hline 27 & Cal.macu & 10 & 17 & 0 & 46 & 27 \\
\hline 28 & Ent.aequ & 8 & 0 & 0 & 81 & 12 \\
\hline 29 & Mic.kitt & 7 & 3 & 1 & 19 & 70 \\
\hline 30 & Tri.lusc & 5 & 4 & 91 & 0 & 0 \\
\hline 31 & Tri.minu & 5 & 13 & 69 & 1 & 12 \\
\hline 32 & Scy.cani & 2 & 2 & 19 & 2 & 75 \\
\hline 33 & Ech.vipe & 1 & 2 & 97 & 0 & 0 \\
\hline 34 & Hip.plat & 0 & 2 & 0 & 69 & 29 \\
\hline 35 & Mel.agle & 0 & 0 & 0 & 33 & 67 \\
\hline 36 & Tri.esm & 0 & 0 & 0 & 30 & 70 \\
\hline 37 & Arg.silu & 0 & 0 & 0 & 100 & 0 \\
\hline 38 & Cal.retic & 0 & 0 & 0 & 100 & 0 \\
\hline 39 & Lum.lampr & 0 & 0 & 0 & 100 & 0 \\
\hline 40 & Ner.oph & 0 & 0 & 0 & 100 & 0 \\
\hline 41 & Pol.poll & 0 & 0 & 0 & 100 & 0 \\
\hline 42 & Pol.vire & 0 & 0 & 0 & 98 & 2 \\
\hline 43 & Hip.hipp & 0 & 0 & 0 & 75 & 25 \\
\hline 44 & Raj.radi & 0 & 0 & 0 & 73 & 27 \\
\hline 45 & Lop.pisc & 0 & 0 & 0 & 70 & 30 \\
\hline 46 & Arg.sphy & 0 & 0 & 0 & 61 & 39 \\
\hline 47 & Lep.whif & 0 & 0 & 0 & 60 & 40 \\
\hline 48 & Cyc.lump & 0 & 20 & 0 & 60 & 20 \\
\hline 49 & Gly.cyno & 0 & 0 & 0 & 47 & 53 \\
\hline 50 & Ana.lupu & 0 & 0 & 0 & 38 & 62 \\
\hline 51 & Seb.vivi & 0 & 0 & 0 & 33 & 67 \\
\hline 52 & Raj.clava & 0 & 0 & 33 & 33 & 33 \\
\hline 53 & Mol.molv & 0 & 5 & 5 & 25 & 65 \\
\hline 54 & Myx.glut & 0 & 0 & 0 & 15 & 85 \\
\hline 55 & Squ.acan & 0 & 3 & 3 & 15 & 79 \\
\hline 56 & Asp.cucu & 0 & 0 & 96 & 1 & 3 \\
\hline 57 & Gad.arge & 0 & 0 & 0 & 0 & 100 \\
\hline 58 & Mus.aste & 0 & 0 & 0 & 0 & 100 \\
\hline 59 & Raj.naev & 0 & 0 & 0 & 0 & 100 \\
\hline 60 & Zeu.fabe & 0 & 14 & 0 & 0 & 86 \\
\hline 61 & Mic.pout & 0 & 0 & 50 & 0 & 50 \\
\hline 62 & Mus.must & 0 & 0 & 100 & 0 & 0 \\
\hline 63 & Raj.mont & 0 & 0 & 100 & 0 & 0 \\
\hline 64 & Spo.cant & 0 & 0 & 100 & 0 & 0 \\
\hline 65 & Tra.drac & 0 & 0 & 100 & 0 & 0 \\
\hline 66 & Gal.gale & 0 & 50 & 50 & 0 & 0 \\
\hline
\end{tabular}

(c) 2009 The Authors, Fish. Oceanogr., 18:1, 36-50. 
Figure 3. Average relative species composition (in \% abundance) in clusters identifying fish assemblages named after water masses: CCC, Continental Coastal Cluster; CNSC, Central North Sea Cluster, CC, Channel Cluster; NNSC, Northern North Sea Cluster; NAC, Northern Atlantic Cluster (see Table 4 for species names). A relative abundance of 0 should not be interpreted as a general non-occurrence of the species in this cluster.

Our results for the North Sea region strongly support the hypotheses of a strong link between hydrographical features such as water masses, fronts and residual currents and bottom fish assemblages. The spatial variability in fish assemblages not explained by hydrographical features might be caused by variation in habitat features such as depth, sediment structure andor substrate type (Daan et al., 1990; Greenstreet and Hall, 1996; Callaway et al., 2002). Menge and Olson (1990) postulated that the relative influence of factors that structure communities depends on the spatial scale. Numerous studies support this conceptual framework. On a regional and local scale, population distribution and relative abundance are mostly influenced by the interaction of physical factors (e.g. depth, seabed structure, substrate) and biological processes such as predator-prey relationships (e.g. Ellis et al., 2000; Callaway et al., 2002; Barletta et al., 2005; Jaureguizar et al., 2006). For instance, within estuaries, salinity and temperature have been found to be major driving forces structuring fish assemblages (Jaureguizar et al., 2004; Barletta et al., 2005), whereas in coastal areas, depth, temperature and substrate have been defined to be the dominating factors (Ellis et al., 2000). Further regional scale studies showed the link between both hydrographical features and bathymetry and bottom fish assemblages, for example in the North Sea (Callaway et al., 2002), the northern Argentine coastal system (Jaureguizar et al.,2006), the Azores Archipelago (Menezes et al., 2006), or the Grand Bank (Gomes and Headrich, 1992). At large spatial scales, patterns of community structure are rather influenced by variation in environmental or climatic conditions, long-range dispersal vectors, nutrients and primary production (Cushing, 1983). For example, a study by Gaertner et al. (2005) demonstrated that bottom fish assemblages in the north-western Mediterranean Sea were structured by hydrographical features such as water masses and fronts rather than by bathymetry.

Accordingly, at a regional North Sea scale it is expected that local variation of water masses and currents derived from climatic differences could result in significant different bottom fish assemblages. Furthermore, the role of fishing in fish community structuring should not be neglected (Piet and Rijnsdorp, 1998; Rogers et al., 1999).

Understanding the degree of variation of fish community structures at biological meaningful spatial scales is a crucial point for spatially explicit manage-

Table 5. Typifying species and percentage contribution to the catch within cluster similarity as identified by SIMPER analysis.

\begin{tabular}{|c|c|c|c|c|c|}
\hline \multirow[b]{2}{*}{ Typifying species } & \multicolumn{5}{|c|}{ Cluster } \\
\hline & $\mathrm{CC}$ & $\mathrm{CCC}$ & CNSC & NAC & NNSC \\
\hline Buglossidium luteum & & 1.77 & & & \\
\hline Callionymus lyra & & 2.87 & 4.70 & & \\
\hline Echiichthys vipera & 7.76 & & & & \\
\hline Eutrigla gurnardus & 5.98 & 12.43 & 9.07 & 4.83 & 7.08 \\
\hline Gadus morhua & 5.95 & 3.48 & 3.17 & & 6.43 \\
\hline Hippoglossoides platessoides & & & & 5.00 & 15.30 \\
\hline Limanda limanda & 4.91 & 40.55 & 27.55 & 9.25 & 24.77 \\
\hline Melanogrammus aeglefinus & & & & 25.12 & \\
\hline Merluccius merluccius & & & & & 17.4 \\
\hline Merlangius merlangus & 54.22 & 23.67 & 36.99 & 29.91 & 15.84 \\
\hline Microstomus kitt & & & & 3.82 & 4.26 \\
\hline Pleuronectes platessa & & 6.98 & 9.15 & & \\
\hline Trisopterus esmarki & & & & 13.31 & \\
\hline Trisopterus luscus & 4.11 & & & & \\
\hline Trisopterus minutus & 10.22 & & & & \\
\hline Average similarity (\%) & 63.12 & 54.69 & 61.61 & 65.73 & 56.29 \\
\hline
\end{tabular}

(c) 2009 The Authors, Fish. Oceanogr., 18:1, 36-50. 


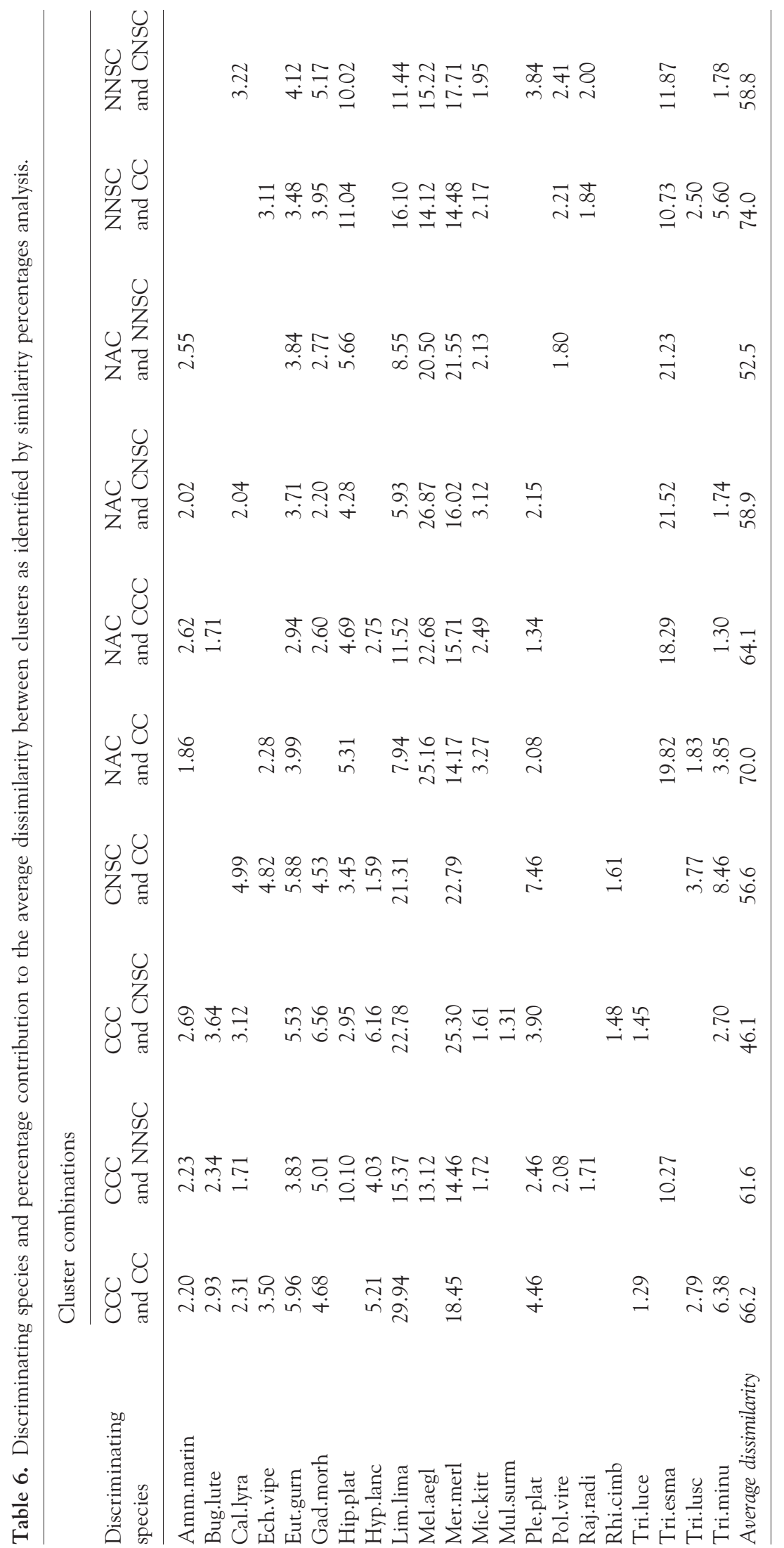

(c) 2009 The Authors, Fish. Oceanogr., 18:1, 36-50. 
ment of marine ecosystems. In the North Sea this is essential for assessments of human impacts on fish communities by wind farms and for development of tools and regulations for ecosystem-based fisheries management such as Marine Protected Areas to recover stocks or protect vulnerable fish habitats. Ultimately, sound evaluation of both spatial and temporal variability will allow for comprehensive impact assessments of climate change.

\section{ACKNOWLEDGEMENTS}

The study was partly funded by the EU-project FINE (Contract No. 98029). We are grateful for helpful comments on hydrography by Dr Gerd Wegner, Institute for Sea Fisheries, Hamburg. We further thank three anonymous referees for helpful comments on an earlier version of the manuscript.

\section{REFERENCES}

Anderson, M.J. (2001) A new method for non-parametric analysis of variance. Aust. J. Ecol. 26:32-46.

Anderson, P.J. and Piatt, J.F. (1999) Community reorganization in the Gulf of Alaska following ocean climate regime shift. Mar. Ecol. Prog. Ser. 189:117-123.

Barletta, M., Barletta-Bergan, A., Saint-Paul, U. and Hubold, G. (2005) The role of salinity in structuring the fish assemblages in a tropical estuary. J. Fish Biol. 66:45-72.

Bray, J.R. and Curtis, J.T. (1957) An ordination of the upland forest communities of Southern Wisconsin. Ecol. Monogr. $27: 325-349$.

Bremner, J., Rogers, S.I. and Frid, C.L.J. (2006) Matching biological traits to environmental conditions in marine benthic ecosystems. J. Mar. Syst. 60:302-316.

Callaway, R., Alsvåg, J.M., de Boois, I. et al. (2002) Diversity and community structure of epibenthic invertebrates and fish in the North Sea. ICES J. Mar. Sci. 59:1199-1214.

Clarke, K.R. (1993) Non-parametric multivariate analyses of changes in community structure. Aust. J. Ecol. 18:117143.

Corten, A. and Van der Kamp, G. (1992) Natural changes in pelagic fish stocks of the North Sea in the 1980s. ICES Mar. Sci. Symp. 195:402-417.

Cushing, D.H. (1983) Sources of variability in the North Sea ecosystem. In: North Sea Dynamics. J. Sündermann \& W. Lenz (eds) Heidelberg: Springer-Verlag Berlin, pp. 498-516.

Daan, N., Bromley, P.J., Hislop, J.R.G. and Nielsen, N.A. (1990) Ecology of North Sea fish. Neth. J. Sea Res. 26:343-386.

Dietrich, G. (1950) Die natürlichen Regionen von Nord- und Ostsee auf hydrographischer Grundlage. Kiel. Meeresforschung, 7:35-69.

Eastwood, P.D., Souissi, S., Rogers, S.I., Coggan, R.A. and Brown, C.J. (2006) Mapping seabed assemblages using comparative top-down and bottom-up classification approaches. Can. J. Fish. Aquat. Sci. 63:1536-1548.

Ehrich, S. and Stransky, C. (2001) Spatial and temporal changes in the southern species component of North Sea bottom fish assemblages. Senckenb. Marit. 31:143-150.
Ehrich, S., Adlerstein, S., Brockmann, U. et al. (2007) 20 Years of the German Small-Scale Bottom Trawl Survey (GSBTS): a review. Senckenb. Marit. 37:13-82.

Ellis, J.R., Rogers, S.I. and Freeman, S.M. (2000) Demersal assemblages in the Irish Sea, St George's Channel and Bristol Channel. Estuar. Coast. Shelf Sci. 51:299-315.

Faith, P., Minchin, P.R. and Belbin, L. (1987) Compositional dissimilarity as a robust measure of ecological distance. Vegetatio 69:57-68.

Gaertner, J.C., Bertrand, J.A., de Sola, L.G., Durbec, J.P., Ferrandis, E. and Souplet, A. (2005) Large spatial scale variation of demersal fish assemblage structure on the continental shelf of the NW Mediterranean Sea. Mar. Ecol. Prog. Ser. 297:245-257.

Gomes, M.C. and Headrich, R.L. (1992) Biogeography of groundfish assemblages on the Grand Bank. J. Northwest Atlantic Fish. Sci. 14:13-27.

Gray, T., Hatchard, J., Daw, T. and Stead, S. (in press) New cod war of words: 'Cod is God' versus 'sod the cod' - two opposed discourses on the North Sea Cod Recovery Programme. Fish. Res. 93:1-7.

Greenstreet, S.P.R. and Hall, S.J. (1996) Fishing and the ground-fish assemblage structure in the north-western North Sea: an analysis of long-term and spatial trends. J. Anim. Ecol. 65:577-598.

Gustafson, E.J. (1998) Quantifying landscape spatial pattern: What is the state of the art? Ecosystems 1:143-156.

Holmes, S.J., Wright, P.J. and Fryer, R.J. (2008) Evidence from survey data for regional variability in cod dynamics in the North Sea and West of Scotland. ICES J. Mar. Sci. 65:206215.

Hsieh, C.H. and Chiu, T.S. (2002) Summer spatial distribution of copepods and fish larvae in relation to hydrography in the Northern Taiwan Strait. Zool. Stud. 41:85-98.

Jaureguizar, A.J., Menni, R., Guerrero, R. and Lasta, C. (2004) Environmental factors structuring fish communities of the Rio de la Plata estuary. Fish. Res. 66:195-211.

Jaureguizar, A.J., Menni, R., Lasta, C. and Guerrero, R. (2006) Fish assemblages of the northern Argentine coastal system: spatial patterns and their temporal variations. Fish. Oceanogr. 15:326-344.

Jennings, S., Kaiser, M.J. and Reynolds, J.D. (2001) Marine Fisheries Ecology. Oxford: Blackwell Science Ltd.

Jørgensen, O.A., Hvingel, C., Møller, P.R. and Treble, M.A. (2005) Identification and mapping of bottom fish assemblages in Davis Strait and southern Baffin Bay. Can. J. Fish. Aquat. Sci. 62:1833-1852.

Knijn, R.J., Boon, T.W., Heessen, H.J.L. and Hislop, R.G. (1993) Atlas of North Sea Fishes. ICES CRR 194:268 pp. Available at: http://www.ices.dk/pubs/crr/crr194/CRR194.pdf.

Laevastu, T. (1963) Surface Water Types of the North Sea and Their Characteristics. Serial Atlas of the Marine Environment. New York: American Geographical Society.

Lee, A. (1970) The currents and water masses of the North Sea. Oceanogr. Mar. Biol. Ann. Rev. 8:33-71.

Lee, A.J. (1980) North Sea: physical oceanography. In: The North-West European Shelf Seas, the seabed and the sea in motion. II. Physical and Chemical Oceanography, and Physical Resources. F.T. Banner, M.B. Collins \& K.S. Massie (eds) Amsterdam: Elsevier, pp. 467-493.

Legendre, P. and Gallagher, E.D. (2001) Ecologically meaningful transformations for ordination of species data. Oecologia 129:271-280. 
Legendre, P. and Legendre, L. (1998). Numerical Ecology, 2nd English edn. Amsterdam: Elsevier.

Legendre, P., Borcard, D. and Peres-Neto, P.R. (2005) Analyzing beta diversity: partitioning the spatial variation of community composition data. Ecol. Monogr. 75:435-450.

Li, W.K.W., Smith, J.C. and Platt, T. (1984) Temperature response of photosynthetic capacity and carboxylase activity in arctic marine phytoplankton. Mar. Ecol. Prog. Ser. 17:237243.

Magnussen, E. (2002) Demersal fish assemblages of Faroe Bank: species composition, distribution, biomass spectrum and diversity. Mar. Ecol. Prog. Ser. 238:211-225.

Mahon, R., Brown, S.K. and Zwanenburg, K.C.T. (1998) Assemblages and biogeography of demersal fishes of the east coast of North America. Can. J. Fish. Aquat. Sci. 55:17041738.

Mantel, N. (1967) The detection of disease clustering and a generalized regression approach. Cancer Res. 27:209-220.

Maravelias, C.D., Reid, D.G. and Swartzman, G. (2000) Modelling spatio-temporal effects of environment on Atlantic herring, Clupea harengus. Environ. Biol. Fishes, 58:157-172.

Menezes, G.M., Sigler, M.F., Silva, H.M. and Pinho, M.R. (2006) Structure and zonation of demersal fish assemblages off the Azores Archipelago (mid-Atlantic). Mar. Ecol. Prog. Ser. 324:241-260.

Menge, B.A. and Olson, A.M. (1990) Role of scale and environmental-factors in regulation of community structure. Trends Ecol. Evol. 5:52-57.

Oksanen, J. (1983) Ordination of boreal heath-like vegetation with principal component analysis, correspondence analysis and multidimensional scaling. Vegetatio 52:181-189.

Oksanen, J., Kindt, R., Legendre, P. and O'Hara, R.B. (2007) vegan: Community Ecology Package Version 1.8-5. http:// cran.r-project.org/.

Otto, L., Zimmermann, J.T.F., Furnes, G.K., Mork, M., Saetre, R. and Becker, G. (1990) Review of the physical oceanography of the North Sea. Neth. J. Sea Res. 26(24): 161-238.

Petitgas, P. (2001) Geostatistics in fisheries survey design and stock assessment: models, variances and applications. Fish Fish. 2:231-249.

Pierce, D.J. and Mahmoudi, B. (2001) Nearshore fish assemblages along the central west coast of Florida. Bull. Mar. Sci. 68:243-270.

Piet, G.J. and Rijnsdorp, A.D. (1998) Changes in demersal fish assemblage in the south-eastern North Sea following the establishment of a protected area ("plaice box"). ICES J. Mar. Sci. 55:420-429.
R Development Team (2007) R: A Language and Environment for Statistical Computing. Vienna: R Foundation for Statistical Computing. ISBN 3-900051-07-0, http://www.R-project.org.

Roemmich, D. and McGowan, J. (1995) Climatic warming and the decline of zooplankton in the California current. Science 267:1324-1326.

Rogers, S.I. and Millner, R.S. (1996) Factors affecting the annual abundance and regional distribution of English inshore demersal fish populations: 1973 to 1995. ICES J. Mar. Sci. 53:1094-1112.

Rogers, S.I., Maxwell, D., Rijnsdorp, A.D., Damm, U. and Vanhee, W. (1999) Fishing effects in northeast Atlantic shelf seas: patterns in fishing effort, diversity and community structure. IV. Can comparisons of species diversity be used to assess human impacts on demersal fish faunas? Fish. Res. 40:135-152.

Sinclair, M. and Iles, T.D. (1985) Atlantic herring (Clupea harengus) distributions in the Golf of Main-Scotian Shelf area in relation to oceanographic features. Can. J. Fish. Aquat. Sci. 42:880-887.

Smouse, P.E., Long, J.C. and Sokal, R.R. (1986) Multipleregression and correlation extensions of the Mantel test of matrix correspondence. Syst. Zool. 35:627-632.

Southward, A.J., Langmead, O., Hardman-Mountford, N.J. et al. (2005) Long-term oceanographic and ecological research in the western English Channel. Adv. Mar. Biol. 47:1-105.

Speckman, S.G., Piatt, J.F., Minte-Vera, C.V. and Parrish, J.K. (2005) Parallel structure among environmental gradients and three trophic levels in a subarctic estuary. Prog. Oceanogr. 66:25-65.

Stelzenmüller, V., Ehrich, S. and Zauke, G.P. (2004) Mesoscaled investigation on spatial distribution of the flatfish species Limanda limanda (Linnaeus, 1758) (dab) within the German Bight: a geostatistical approach. In: 2nd International Symposium on GISSpatial Analysis in Fisheries and Aquatic Scien. T. Nishida, P.J. Kailola \& C.E. Hollingworth (eds) Brighton: Fishery/Aquatic GIS Research Group, pp. 251-269.

Stelzenmüller, V., Ehrich, S. and Zauke, G.P. (2005) Effects of survey scale and water depth on the assessment of spatial distribution patterns of selected fish in the northern North Sea showing different levels of aggregation. Mar. Biol. Res. $1: 375-387$.

Sullivan, M.C., Cowen, R.K. and Steves, B.P. (2005) Evidence for atmosphere-ocean forcing of yellowtail flounder (Limanda ferruginea) recruitment in the Middle Atlantic Bight. Fish. Oceanogr 14:386-399.

Tomczak, G. and Goedecke, E.. (1964) Die thermische Schichtung der Nordsee und Monatskarten der Temperatur der Nordsee. Ergänzungsh. Dtsch. Hydrogr. Z. Reihe B (4) 8:1-182. 